
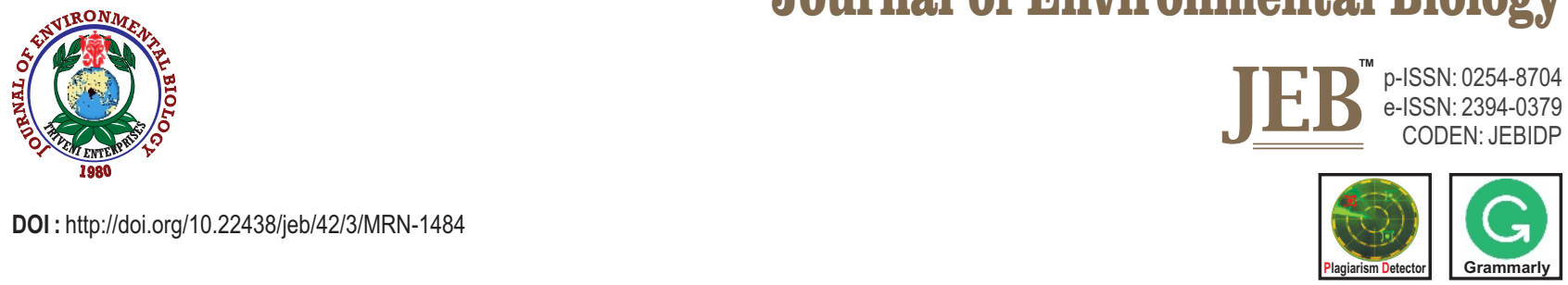

\title{
Impact of different drying methods on nutritional quality of Garcinia cowa and Garcinia pedunculata fruits
}

\author{
I. Sagolsem 1 , S. Rathi' and S. Baishya ${ }^{2 *}$ \\ 'Department of Food Science and Technology, Assam Agricultural University, Jorhat-785 013, India \\ ${ }^{2}$ Department of Biochemistry and Agricultural Chemistry, Assam Agricultural University, Jorhat-785013, India \\ *Corresponding Author Email : samindra.baishya@aau.ac.in
}

\section{Abstract}

Aim: The present study was undertaken to establish a suitable drying process for Garcinia cowa and Garcinia pedunculata fruits for maximum retention of their nutritional qualities.

Methodology: Slices of three different thickness with $0.3,0.6,0.9 \mathrm{~cm}$ of $\mathrm{G}$. cowa and $G$. pedunculata fruits were dried by sun drying, solar drying and by cabinet drying at three different temperatures $\left(50^{\circ} \mathrm{C}, 70^{\circ} \mathrm{C}\right.$ and $90^{\circ} \mathrm{C}$ ).

Results: The mean crude fat and ash content were higher in $G$. cowa than $G$. pedunculata while later was found rich in crude protein and Fe contents. Total phenol content ranged between 881.31-888.65 and $719.00-736.74 \mathrm{mg}$ gallic acid equivalent $100 \mathrm{~g}^{-1}$, total flavonoid content between 89.21-90.06 and 51.00-52.54 mg quercetin equivalent $100 \mathrm{~g}^{-1}$ and mean HCA contents ranged between $3.13-3.92 \%$ and 1.84 $1.99 \%$ for G. cowa and G. pedunculata, respectively. The methanolic extracts exhibited significant antioxidant activity. With lower $I C_{50}$ values, $G$. cowa had higher antioxidant activity than $G$. pedunculata.

Interpretation: Oven drying at $50^{\circ} \mathrm{C}$ and $0.9 \mathrm{~cm}$ slice thickness for drying resulted in better retention of total phenolic and flavonoid contents with better antioxidant activities.

Key words: Antioxidant, Borthekera, Drying method, Garcinia, Kujithekera

How to cite : Sagolsem, I., S. Rathi and S. Baishya: Impact of different drying methods on nutritional quality of Garcinia cowa and Garcinia pedunculata fruits. J. Environ. Biol., 42, 714-719 (2021).

Five different drying methods each with three different slice thickness of Garcinia cowa and Garcinia pedunculata fruits were used for nutritional evaluation

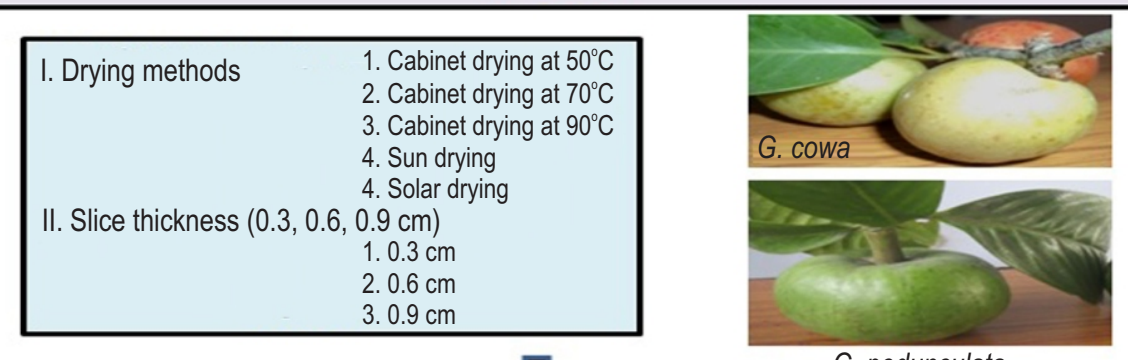

I

Different nutritional parameters like crude protein, crude fat, ash, iron, calcium, hydroxycitric acid, phenol, flavonoids, antioxidant activity etc. were assessed

The results based on ANOVA, showed significant differences in respect of thickness of slices and drying methods for all the parameters studied. Oven drying at $50^{\circ} \mathrm{C}$ and $0.9 \mathrm{~cm}$ slice thickness for drying resulted in better retention of total phenolic and flavonoid contents with better antioxidant activities. 


\section{Introduction}

The genus Garcinia (Family: Clusiaceae) is one of the underutilized fruit crops with potential therapeutic properties, consisting over 200 species distributed in the tropics of the world. In India, there exist about 35 species of Garcinia which are endemic with substantial medicinal properties. Garcinia pedunculata, G. kydia, G. cowa and G. lancifolia are some important species of North Eastern parts of India. Many species of Garcinia have fruits with edible arils and have tremendous potential as spice and medicinal plants. The dried fruit rind with sweet acid taste is traditionally used for culinary purposes as a condiment and flavouring agent. In North-Eastern India, the sun-dried slices of garcinia fruits are used for edible and curative purposes (Gogoi et al., 2016). Garcinia cambogia, G. indica and G. cowa are some of the cultivated species in some parts of India.

Garcinia is a rich source of secondary metabolites with bioactive phytochemicals. Many of the isolated compounds possess anticancer, anti-inflammatory, antibacterial, antiviral, antifungal, anti-HIV, antidepressant and antioxidant properties. Garcinol present in Garcinia is found to elicit anti-cancer properties by regulating different cellular processes (Aggarwal et al., 2020). Nhan et al. (2020) isolated several xanthone derivatives from $G$. delpayana that showed potential antiinflammatory properties. Traditional use of $G$. cambogia fruit pericarp extracts in multiple traditional medicinal system to treat bacterial diseases and cancer was validated by Hart and Cock (2016). The juice and ethanolic extract of G. mangostana leaves have possible antifungal and antibacterial activity (Diniatik et al., 2019) whereas the fruit rind of $G$. indica has significant antidepressant and anxiolytic effect (Dhamija et al., 2017). The main component of fruit rind is garcinol, isogarcinol and camboginol. Garcinol and isogarcinol in various Garcinia species are reported to have activity against cancer, pathogenic bacteria, parasite infections and various inflammatory diseases (Schobert and Biersack, 2019). The antioxidant activity of garcinol has been identified as the basis for various bioactivities in Garcinia (Liyanagamage et al., 2020). The major organic acid in the fruit rind of Garcinia is hydroxycitric acid (HCA), a proven natural antiobese agent (Onakpoya et al., 2011). Tomar et al. (2019) reported the anti-obesity effects of HCA with the help of clinical data and metabolic model analysis. They found that HCA treatment reduced body weight gain and fat accumulation in obese subjects. Hydroxyxitric acid has been proved to combat obesity by promoting reduced glucose absorption, decreased appetite and improved lipid profile (Ferreira et al., 2020).

In Assam, Garcinia is commonly known as "thekera" has rich traditional uses. Young leaves are eaten by some tribes, the latex of G. cowa is used in Thai folk medicines as an antifever agent, also used for menstrual problems, dysentery and fever in traditional system of medicine. Two of the Garcinia species of this region, G. cowa Roxb.," and G. pedunculata Roxb., locally known as "kujithekera and borthekera" are popular for their acidic fruits and dried fruit slices are preserved for preparing different dishes and to treat dysentery. Folk people use cold water infusion of dry pericarp as antidiarrhoeic, antidysentric, in dyspepsia and flatulence (Kagyung et al., 2010). The sun-dried slices of $G$. pedunculata are also used in culinary purposes. The fruits of both these species are rich in hydroxycitric acid. Despite health benefits of Garcinia, the fruits of G. cowa and G. pedunculata remain underutilized. Fruits are highly perishable and needs preservation for use during off season. Drying helps their storage at ambient temperature. Open sun drying (OSD) is the most common method of drying practised for Garcinia fruits in Assam. However, the method is affected by different factors like wind speed, relative humidity, product thickness, effective sun-shine hours etc. This is a slow drying process with chances of mold growth deteriorating the quality of dried products. Two other drying methods commonly practised include solar drying and oven drying. However, drying might cause degradation of nutritional substances with undesirable colour changes of the products. The present study was, therefore, designed to establish a suitable drying method for Garcinia species and to assess its effects on the nutritional quality of dried products.

\section{Materials and Methods}

About $15 \mathrm{~kg}$ of fresh, mature fruits of $\mathrm{G}$. cowa and $\mathrm{G}$. pedunculata, just before ripening were collected from the Experimental Farm, Department of Horticulture, Assam Agriculture University, Jorhat. Fruits were washed thoroughly under running tap water and wiped dry. The unpeeled fruits were cut into half, seeds removed and then sliced to the required thickness, $0.3,0.6$ and $0.9 \mathrm{~cm}$ using mechanical slicer. Slices of two fruit species were spread over aluminium tray separately for sun drying. Oven drying was performed in the electrical tray dryer at three different temperatures set at $50^{\circ} \mathrm{C}, 70^{\circ} \mathrm{C}$ and $90^{\circ} \mathrm{C}$. Solar drying was carried out by keeping the slices at solar cabinet dryer designed by Rajasthan Agricultural University, Udaipur, India. The weight of dried slices was determined at intervals of 2 hours till constant or near constant weight were obtained. After complete dryness, the samples were allowed to cool, slices were ground to form a powder, sieved (20 mesh), packed in a zip lock polyethene bag and stored at room temperature for further analysis.

Moisture content, titratable acidity, total soluble solids, $\mathrm{pH}$, crude fat, crude protein, ash content were determined as per the procedure of $A O A C(2000)$. The moisture content of fruits and slices of different thickness was determined gravimetrically by subtracting the weight of dried sample from the weight of fresh sample. The titratable acidity of flesh juice was estimated by the volumetric method using phenolphthalein as an indicator and expressed as grams of citric acid per $100 \mathrm{ml}$. Total soluble solid were read using Abbe's hand refractometer $\left(0-32^{\circ} \mathrm{C}\right)$ having automatic temperature correction facility and was expressed in ${ }^{\circ}$ Brix. The $\mathrm{pH}$ of flesh juice was determined by a glass electrode $\mathrm{pH}$ meter. Crude fat was determined by automatic fat extraction unit (SOCS PLUS, Pelican, India) using petroleum ether as an extracting solvent and was expressed as a percentage of crude 
fat on moisture free basis. Crude protein content was determined by micro Kjeldahl method using automatic digestion unit (KELPLUS, model KES04L, Pelican, India), followed by distillation and titration and the nitrogen content was multiplied by a factor (6.25) to calculate protein content. Ash content was determined using 5 $\mathrm{g}$ moisture free powdered sample in a silica crucible, charred in low Bunsen flame and finally ignited at $600^{\circ} \mathrm{C}$ for $6 \mathrm{hrs}$ in the muffle furnace and ash was dissolved in $\mathrm{HCl}$ (1:1) on a water bath at $100^{\circ} \mathrm{C}$ and the solution was evaporated to dryness, volume made up to $100 \mathrm{ml}$ with glass distilled water. Iron content was determined following the method described of Wong (1928) using UV-Visible spectrophotometer (Chemito, UV -2100 model).

The concentration of iron present in the sample was calculated from the standard curve (taking iron as standard) and expressed as mg Fe $100 \mathrm{~g}^{-1}$ sample. Calcium was determined using flame photometer as per the method described by AOAC (1984). A stock solution of calcium (200 ppm) was prepared and different concentrations of the solution were placed under Nebuliser and the intensity of emitted lights was measured. The concentration of sample solution was calculated from the standard curve prepared using calcium. HCA was determined by the spectrophotometric method as described by Benny et al. (1999). A standard was prepared by using ethylenediamine salt of HCA ( $98 \%$ ED-HCA). The absorbance of slight orange colour was read in UV-visible spectrophotometer (Varian Cary 50 Scan) at $467 \mathrm{~nm}$. The amount of HCA in the sample was calculated from the standard graph. Total phenol was assayed following the method of Singleton and Rossi (1965) as described by Malik and Singh (1980) using Folin-Ciocalteau reagent in alkaline medium to produce a blue-coloured complex (molybdenum blue) and the absorbance was read on UV-visible spectrophotometer (Varian Cary 50 Scan) at $650 \mathrm{~nm}$ expressing total phenol as $\mathrm{mg}$ catechol $100 \mathrm{~g}^{-1}$ sample.

Total flavonoids content were determined by spectrophotometric assay based on aluminium complex formation initially proposed by Christ and Müller (1960) and as described by Aiyegroro and Okoh (2010) and the absorbance was read at $415 \mathrm{~nm}$ on a UV-visible spectrophotometer (Varian Cary 50 Scan). Quercetin was used as standard and the result was expressed as $\mathrm{mg}$ of quercetin equivalents $100 \mathrm{~g}^{-1}$ d.wt. Antioxidant activity was measured by the method of Blois (1958) and as described by Vani et al. (1997) using DPPH. The concentration of the sample required to decrease the DPPH concentration by $50 \%$ was obtained by interpolation from the linear regression curve and denoted $I_{50}$ value $(\mu \mathrm{g})$ using ascorbic acid as a reference compound. The reducing power of Garcinia samples was determined by the method of Oyaizu (1986). The absorbance was measured at $700 \mathrm{~nm}$ and ascorbic acid was used as standard. Increased absorbance of the reaction mixture indicates an increase in reducing power and reducing power was expressed as L-ascorbic acid equivalent per $100 \mathrm{~g}^{-1}$ dry sample. The results obtained were subjected to analyses of variance in factorial completely randomized design with three replications to interpret the results. All drying operations and chemical analyses for fresh fruits and slices of three different thicknesses were carried out in triplicate.

\section{Results and Discussion}

The results of the study based on ANOVA (Table 1, 2) showed significant differences on the nutrient and phyto-chemical composition of two Garcinia species-G. cowa and G. pedunculata with respect to thickness of fruit slices and drying methods used in the study. Garcinia cowa was found superior over G. pedunculata in different parameters studied. G. cowa fruits were rich in different nutritive constituents such as crude fat, crude protein, ash, calcium, iron etc., than that of G. pedunculata (Table 3). Higher phenolics and flavonoid contents in Carissa edulis Vahl dried fruits was reported to have higher antioxidant activity with better $I_{50}$ values and thus can act as a good free radical scavenger (Fowsiya and Madhumitha, 2017). Higher proportion of phenolic compounds in $\mathrm{G}$. cowa with better $\mathrm{IC}_{50}$ value and reducing power might be useful as a potential preventive intervention for free radicals mediated diseases. The moisture content of whole fruits of G. cowa and G. pedunculata were found

Table 1:Analysis of variance of thickness, drying techniques and interaction for $G$. cowa

\begin{tabular}{|c|c|c|c|c|c|c|c|c|c|c|}
\hline \multirow{3}{*}{$\begin{array}{l}\text { Source of } \\
\text { Variation }\end{array}$} & \multicolumn{4}{|l|}{ d.f } & \multicolumn{6}{|c|}{ Means Squares } \\
\hline & & $\begin{array}{l}\text { Crude } \\
\text { fat }(\%)\end{array}$ & $\begin{array}{l}\text { Crude } \\
\text { protein (\%) }\end{array}$ & $\begin{array}{l}\text { Ash } \\
(\%)\end{array}$ & $\mathrm{Fe}$ & $\mathrm{Ca}$ & $\begin{array}{l}\mathrm{HCA} \\
(\%)\end{array}$ & $\begin{array}{l}\text { Total } \\
\text { phenol }\end{array}$ & $\begin{array}{l}\text { Total } \\
\text { flavonoid }\end{array}$ & $\begin{array}{l}\mathrm{IC}_{50} \\
\left(\mu \mathrm{g} \mathrm{ml^{-1 }}\right)\end{array}$ \\
\hline & & & & & \multicolumn{2}{|c|}{$\left(\mathrm{mg} \mathrm{100 \textrm {g } ^ { - 1 } )}\right.$} & & $\overline{\left(\mathrm{mg} \mathrm{100g^{-1 } )}\right.}$ & & \\
\hline Thickness & 2 & 0.001 & $0.239^{*}$ & $0.006^{*}$ & $1.374^{*}$ & $1.436^{*}$ & $2.545^{*}$ & 254.813 & $2.767^{*}$ & $5.184^{*}$ \\
\hline Drying method & 4 & $0.023^{*}$ & $1.989^{*}$ & $0.019^{*}$ & $7.490^{*}$ & $5.623^{*}$ & $1.155^{*}$ & $8,321.777^{*}$ & $263.240^{*}$ & $4.591^{*}$ \\
\hline $\begin{array}{l}\text { Interaction of } \\
\text { thickness and } \\
\text { drying method }\end{array}$ & 8 & 0.001 & $0.074^{*}$ & 0.000 & $0.074^{*}$ & $0.166^{*}$ & 0.204 & 285.956 & $0.615^{*}$ & $1.744^{*}$ \\
\hline Error & 30 & 0.001 & 0.000 & 0.000 & 0.000 & 0.000 & 0.202 & 185.612 & 0.265 & 0.004 \\
\hline
\end{tabular}

${ }^{*}$ Significant at $5 \%$ probability level 
Table 1: Analysis of variance of thickness, drying techniques and interaction for G. pedunculata

\begin{tabular}{|c|c|c|c|c|c|c|c|c|c|c|}
\hline \multirow{3}{*}{$\begin{array}{l}\text { Source of } \\
\text { variation }\end{array}$} & \multirow{3}{*}{$\begin{array}{l}\text { Degree of } \\
\text { freedom }\end{array}$} & \multicolumn{9}{|c|}{ Means Squares } \\
\hline & & \multirow[t]{2}{*}{$\begin{array}{l}\text { Crude } \\
\text { fat (\%) }\end{array}$} & \multirow[t]{2}{*}{$\begin{array}{l}\text { Crude } \\
\text { protein (\%) }\end{array}$} & \multirow[t]{2}{*}{$\begin{array}{l}\text { Ash } \\
(\%)\end{array}$} & $\mathrm{Fe}$ & $\mathrm{Ca}$ & $\begin{array}{l}\text { HCA } \\
(\%)\end{array}$ & $\begin{array}{l}\text { Total } \\
\text { phenol }\end{array}$ & $\begin{array}{l}\text { Total } \\
\text { flavonoid }\end{array}$ & $\begin{array}{l}\mathrm{IC}_{50} \\
\left(\mu \mathrm{g} \mathrm{m}^{-1}\right)\end{array}$ \\
\hline & & & & & \multicolumn{2}{|c|}{$\left(\mathrm{mg} \mathrm{100 \textrm {g } ^ { - 1 } )}\right.$} & & \multicolumn{2}{|l|}{$\left(\mathrm{mg} \mathrm{100 \textrm {g } ^ { - 1 } )}\right.$} & \\
\hline Thickness & 2 & $0.006^{*}$ & 0.119 * & $0.002^{*}$ & $3.618^{*}$ & $3.282^{*}$ & 0.096 & $1,248.306^{*}$ & $11.479^{*}$ & $17.916^{*}$ \\
\hline Drying method & 4 & $0.006^{*}$ & $0.870^{*}$ & $0.057^{*}$ & $25.517^{\star}$ & $2.844^{*}$ & $0.590^{*}$ & $24,202.928^{*}$ & $288.231^{*}$ & $2.675^{\star}$ \\
\hline $\begin{array}{l}\text { Interaction of } \\
\text { thickness and } \\
\text { drying method }\end{array}$ & 8 & $0.004^{*}$ & $0.056^{*}$ & $0.001^{*}$ & $2.119^{*}$ & $0.330^{*}$ & 0.108 & $1,699.436^{*}$ & $11.372^{*}$ & $10.666^{*}$ \\
\hline Error & 30 & 0.000 & 0.019 & 0.001 & 0.000 & 0.000 & 0.073 & 52.791 & 0.082 & 0.708 \\
\hline Total & 44 & & & & & & & & & \\
\hline
\end{tabular}

${ }^{*}$ Significant at $5 \%$ probability level

Table 3: Biochemical characteristics of Garcinia cowa and Garcinia pedunculata fruits

\begin{tabular}{lll}
\hline Composition & G. cowa & G. pedunculata \\
\hline Moisture (\%) & $88.17 \pm 0.03$ & $88.47 \pm 0.05$ \\
Total titratable acidity (\%) & $1.65 \pm 0.30$ & $2.13 \pm 0.28$ \\
Total soluble solid ( ${ }^{\circ}$ Brix) & $9.06 \pm 0.90$ & $6.06 \pm 0.25$ \\
Juice pH & $1.78 \pm 0.03$ & $1.80 \pm 0.05$ \\
Crude fat (\%) & $1.35 \pm 0.02$ & $1.25 \pm 0.02$ \\
Crude protein (\%) & $3.95 \pm 0.14$ & $4.97 \pm 0.19$ \\
Ash content $(\%)$ & $2.49 \pm 0.25$ & $1.86 \pm 0.03$ \\
Iron content $(\mathrm{mg} / 100 \mathrm{~g})$ & $11.9 \pm 0.01$ & $17.51 \pm 0.02$ \\
Calcium content $(\mathrm{mg} / 100 \mathrm{~g})$ & $15.17 \pm 0.12$ & $14.66 \pm 0.01$ \\
HCA content $(\%)$ & $4.29 \pm 0.03$ & $2.57 \pm 0.01$ \\
Total phenol content $(\mathrm{mg} / 100 \mathrm{~g})$ & $922.50 \pm 0.02$ & $819.38 \pm 0.04$ \\
Total flavonoid content $(\mathrm{mg} / 100 \mathrm{~g})$ & $99.31 \pm 0.02$ & $59.88 \pm 0.03$ \\
\hline
\end{tabular}

*Values represented in the table are mean \pm SD of three replication

to be 88.17 and $88.47 \%$ (wet basis). Drying to a constant moisture level was found to be dependent on the thickness of material and drying method used. Thinner the slices, shorter were the time required for drying in all the drying methods and higher temperature, lower was the time required to achieve a constant weight. In the present study, with slice thicknesses of 3, 6 and 9 $\mathrm{mm}$ and oven temperature of $50^{\circ} \mathrm{C}$, the time required for drying was found to be 4.5, 7.5 and $8.5 \mathrm{hrs}$ for $\mathrm{G}$. cowa and 5,7 and 8.5 hrs for $G$. pedunculata, respectively. With rise in oven temperature, time requirement was lowered. Solar drying was found more effective over sun drying in reducing the moisture content to a constant level in Garcinia slices. For G. cowa, sun drying was completed in 7-11 days (40.5-61 BSSH) depending on slice thickness where as 6-8 days (35.8-46.4 BSSH) were required to reduce the moisture content to a constant level by solar drying. For $G$. pedunculata, sun drying required 8-10 days (39.5-48.1 BSSH), while solar dryer drying was completed in 6-8 days (28.7-39.5 BSSH). The requirement of lesser time for solar drying might be due to higher temperature available within the dryer (Das and Sarma, 2001). During study, maximum $18^{\circ} \mathrm{C}$ higher temperature than the ambient was recorded in the solar dryer. All the drying methods used in the study were found suitable for the production of dried Garcinia for safe storage.

The methods will produce semi-moist products, however, due to high acidic content of the fruits, they can be easily preserved. Crude fat content was higher in G. cowa (1.35\%), but G. pedunculata was found as a better source of crude protein with $4.97 \%$ than $G$. cowa with $3.95 \%$. In dried slices, crude fat varied between $1.12-1.28 \%$ in $G$. cowa and $1.12-1.21 \%$ in $G$. pedunculata. However, crude fat contents in different Garcinia species were reported to be lower than these values (Nurminah et al., 2019). Drying resulted in the loss of crude fat content in Garcinia, with lowest average fat content in oven dried samples dried at $90^{\circ} \mathrm{C}$. This might be due to volatilization of low molecular weight fatty materials. Drying methods had a significant effect on the crude protein content in Garcinia, higher temperature was found to lower the crude protein content.

The average crude protein content in dried $G$. cowa was 2.83-3.08\% and $4.47-4.65 \%$ in G. pedunculata. The effect of slice 
thickness on crude protein content was also found significant. Higher the slice thickness, greater was the crude protein content in dried Garcinia. Slice thicknesses and drying temperatures showed significant effects on the ash content in Garcinia. The average ash content in G. cowa was $2.13-2.18 \%$ and in $G$. pedunculata, it ranged between $1.60-1.62 \%$. Increased slice thickness and higher temperature resulted in higher ash content. Highest ash content was found in samples oven dried at $90^{\circ} \mathrm{C}$ and the slices of $0.9 \mathrm{~cm}$ thickness. On dry weight basis, $G$. pedunculata had more iron content than $G$. cowa. Oven dried $\left(50^{\circ} \mathrm{C}\right)$ samples showed the highest iron content.

The average calcium content in $\mathrm{G}$. cowa was 13.32-13.91 $\mathrm{mg} 100 \mathrm{~g}^{-1}$ and $12.92-13.85 \mathrm{mg} 100 \mathrm{~g}^{-1}$ in G. pedunculata, respectively. With the increase in slice thickness, iron and calcium contents were found increasing significantly in both $\mathrm{G}$. cowa and $G$. pedunculata. Sun-dried thicker slices were found to retain maximum calcium while solar drying resulted in least. Higher temperature may cause some leaching and loss of minerals leading to some error in estimation. Hydroxycitric acid (1,2dihydroxypropane-1,2,3-tricarboxylic acid) is the principal organic acid present in the fruit rind of Garcinia species. Garcinia cowa is a better source of HCA than G. pedunculata with $4.29 \%$ and $2.57 \% \mathrm{HCA}$ in the two species respectively on a dry weight basis. There were significant effects of slice thickness, drying methods and their interactions on HCA content in Garcinia species. Drying methods caused a reduction in $\mathrm{HCA}$ content. The maximum $\mathrm{HCA}(4.06 \%)$ was observed in the slices dried at $70^{\circ} \mathrm{C}$ in case of $\mathrm{G}$. cowa, while in $\mathrm{G}$. pedunculata, the maximum $\mathrm{HCA}$ $(2.25 \%)$ was found in oven dried slices at $90^{\circ} \mathrm{C}$. Bainto et al. (2018) reported that samples dried at $60^{\circ} \mathrm{C}$ yielded the highest concentration of $\mathrm{HCA}(4.46 \%)$, followed by $70^{\circ} \mathrm{C}(4.22 \%)$ and $50^{\circ} \mathrm{C}(4.03 \%)$ in $\mathrm{G}$. binucao fruit pulp.

Garcinia cowa and G. pedunculata had 922.50 and $819.38 \mathrm{mg}$ catechol equivalent of phenol $100 \mathrm{~g}^{-1}$ which was reduced during drying. Decrease in TPC during drying could probably be attributed to binding of polyphenols with other compounds (proteins) or alterations in the chemical structure of polyphenols which cannot be extracted or determined by available methods (Qu et al., 2010). In dried material, highest average total phenol content was found in oven dried materials dried at $90^{\circ} \mathrm{C}$ and the lowest was recorded for the sun-dried materials. The high retention of phenolic compounds in Garcinia slices dried at $90^{\circ} \mathrm{C}$ could be due to the availability of precursors for non-enzymatic inter-conversion between phenolic molecules (Vega-Galvez et al., 2009). Moreover, faster drying rate at $90^{\circ} \mathrm{C}$ might decrease the degradation of TPC through the oxidation process. The higher total phenolics might also possibly due to the liberation of phenolic compounds from the matrix during the drying process. Lower drying temperatures probably did not inactivate the oxidative enzymes completely, which might have in turn, resulted in oxidation of the phenolic substances and resulted in a relatively lower phenolic content.
Drying also caused a decrease in the total flavonoid content in Garcinia under study. Total flavonoid content in G. cowa was decreased from 99.31 to $89.21-90.06 \mathrm{mg} Q \mathrm{QE} / 100 \mathrm{~g}$ and from 59.88 to $51.00-52.54 \mathrm{mg} \mathrm{QE} / 100 \mathrm{~g}$ in $\mathrm{G}$. pedunculata. The loss of flavonoids during drying may be due to the process conditions, in particular, the temperature and duration (Michalczyk et al., 2009; Schieber et al., 2001). Effect of slice thickness, drying methods and their interaction were significant for flavonoid content. Mean total flavonoid content was highest in the oven dried materials dried at $50^{\circ} \mathrm{C}(98.98$ and $57.86 \mathrm{mg} Q \mathrm{QE} / 100 \mathrm{~g})$ and the lowest was recorded for the sundried materials (85.15 and $44.02 \mathrm{mg} \mathrm{QE} / 100$ g) for G. cowa and G. pedunculata respectively. Slices with $0.6 \mathrm{~cm}$ thickness showed the highest flavonoid contents. Both total phenol and flavonoids can act as free radical scavenges. The free radical scavenging activities of Garcinia species were co-related to both phenolic and flavonoid contents (Gogoi et al., 2015). DPPH system is one of the most widely used tools in determining free radical scavenging activities of antioxidants. Free radical scavenging activities were found higher in $G$. cowa than in $G$. pedunculata because of higher total phenol and total flavonoid contents in G. cowa. There was an increased activity with the increased concentration of the extract. The highest activity was shown by $50^{\circ} \mathrm{C}$ oven dried sample at $100 \mu \mathrm{g}$ concentration for both $G$. cowa $(84.9 \pm 0.03 \%$ inhibition) and G. pedunculata (77.6 $\pm 0.04 \%$ inhibition). Standard ascorbic acid showed higher $(93.32 \pm 0.03 \%$ inhibition) activities at the same concentration.

There were significant differences in the $I C_{50}$ values for the slices of different thicknesses dried through different methods. Lowest $I C_{50}$ values were found for the samples dried at $50^{\circ} \mathrm{C}$ and the highest with sun-dried samples. Sun-dried samples of both $G$. cowa and $G$. pedunculata had the lowest total phenol and flavonoid contents and hence the highest $\mathrm{IC}_{50}$ value. Sundrying was reported inferior to retain quality of dried Garcinia cambogia by Lim et al. (2020). Higher antioxidant activity in the $50^{\circ} \mathrm{C}$ oven dried samples might be due to the combined action of phenols, flavonoids and other compounds.

Garcinia cowa extracts also showed higher ferric reducing antioxidant power than Garcinia pedunculata. Garcinia cowa was found to be a better source of nutrients and phytochemicals than G. pedunculata. Drying lowered the nutrient and phytochemical contents of Garcinia species. Oven drying was found better over the sun and solar drying. The thickness of slices was also found to have significant effects on the nutritional quality. Comparatively, oven drying at $50^{\circ} \mathrm{C}$ and $0.9 \mathrm{~cm}$ material thickness for drying resulted in better retention of total phenolic and flavonoid contents with better antioxidant activities.

\section{Acknowledgment}

We thank Assam Agricultural University, Jorhat, Assam, India for providing facility and funds for carrying out the research. 


\section{Add-on Information}

Authors' contribution: I. Sagolsem: Resources, Methodology, Investigation; S. Rathi: Data analysis, writing original draft; S. Baishya: Data analysis, writing final draft.

Research content: The research content of manuscript is original and has not been published elsewhere.

\section{Ethical approval: Not applicable}

Conflict of interest: The authors declare that there is no conflict of interest.

\section{Data from other sources: Not applicable}

Consent to publish: All authors agree to publish the paper in Journal of Environmental Biology.

\section{References}

Aggarwal, V., H.S. Tuli, J. Kaur, D. Aggarwal, G. Parashar, N.C. Parashar, S. Kulkarni, G. Kaur, K. Sak, M. Kumar and K.S. Ahn: Garcinol exhibits anti-neoplastic effects by targeting diverse oncogenic factors in tumor cells. Biomedicines, 8, 103 (2020). Doi : 10.3390/biomedicines8050103

Aiyegroro, O.A. and A.I. Okoh: Preliminary phytochemical screening and in-vitro antioxidant activities of aqueous extract of Helichrysum longifolium DC. BMC Complement. Altern. Med., 10, 21 (2010).

AOAC: Official Methods of Analysis. Association of Official Analytical Chemists, Washington DC (1984).

AOAC: Official Methods of Analysis. Association of Official Analytical Chemists, Washington DC (2000).

Bainto, L.C., E.I. Dizon and K.A.T Castillo-Israel: Effects of various processing methods on hydroxycitric acid content of "batuan" [Garcinia binucao (Blanco) Choisy] fruits. Int. Food Res. J., 25 (Suppl.1), S13-S19(2018).

Benny, A., M. Elias and W. Varghese: Spectrophotometric determination of hydroxycitric acid. Indian J. Pharm. Sci., 5, 316-317 (1999).

Blois, M. S.:Antioxidant determinations by the use of a stable free radical. Nature, 181, 1199-1200 (1958).

Christ, B. and K.H. Müller: Zur serienmaessigen Bestimmung des Gehaltes an Flavonol-Derivaten in Drogen. Arch. Pharm., 293, 1033-1042 (1960).

Das, P. and S.K. Sarma: Drying of ginger using solar cabinet dryer. J. Food Sci. Technol., 38, 619-621 (2001).

Dhamija, I., M. Parle and S. Kumar: Antidepressant and anxiolytic effects of Garcinia indica fruit rind via monoaminergic pathway. 3 Biotech, 7,131 (2017)

Diniatik, D., E. Sundhani, M.T. Nugroho, E.N. Hikmah, R. Wahyuningrum and Soparman: Antifungal and antibacterial activities of juice and ethanolic extracts of Garcinia mangostana $\mathrm{L}$. leaves. Asian J. Pharm. Clin. Res., 12, 103-106 (2019).

Ferreira, C.D.N.T., L.C. Carnevali, D.C. Gonçalves, G.C.L. da Silva, A.L. Hoefel: Efficacy of Garcinia cambogia as adjuvant in the treatment of obesity and associated diseases. Adv. Nutri. Food Sci., 2020, ANAFS-168 (2020)

Fowsiya, J. and G. Madhumitha: Preliminary phytochemical analysis, antioxidant and cytotoxicity test of Carissa edulis Vahl dried fruits. IOP Conf. Ser., Mater. Sci. Eng., 263, 022018 (2017).

Gogoi, B., R.P. Das, U. Barua and R. Boruah: Ethno-botanical survey of Garcinia species of Assam. Int. J. Biores. Stress Manage., 7, 752-
$755(2016)$.

Gogoi, N., A. Gogoi and B. Neog: Free radical scavenging activities of Garcina xanthochymus Hook. F. and Garcinia lanceafolia Roxb. using various in-vitro assay models. Asian J. Pharm. Clin. Res., 8, 138-141 (2015).

Hart, C. and I.E. Cock: An examination of the antimicrobial and anticancer properties of Garcinia cambogia fruit pericarp extracts. BEMS Reports, 2, 23-26 (2016).

Kagyung, R., P.R. Gajurel, P. Rethy and B. Singh: Ethnomedicinal plants used for gastrointestinal diseases by Adi tribes of Dehang-Debang Biosphere Reserve in Arunachal Pradesh. Indian J. Tradit. Knowl., 9, 496-501 (2010).

Lim, G.W., S. Jafarzadeh and M.R. Norazatul Hanim: Kinetic study, optimization and comparison of sun drying and superheated steam drying of asam gelugor (Garcinia cambogia). Food Res., 4, 396-406 (2020).

Liyanagamage, D.S. N.K., S. Jayasinghe, A.P. Attanayake and V. Karunaratne: Correlation between antioxidant activity and the garcinol content released from fruit rinds of endemic Garcinia quaesita Pierre on different cooking conditions. J. Food Quality, Article ID 7389714 (2020). http://doi.org/10.1155/2020/7389714

Malik, E.P. and M.B. Singh: Plant Enzymology and Hittoenzymology. Kalyani Publishers, New Delhi, p. 286 (1980).

Michalczyk, M., R. Macura and I. Matuszak: The effect of air-drying, freezedrying and storage on the quality and antioxidant activity of some selected berries. J. Food Process Preserv., 33, 11-21 (2009).

Nhan, N.T., P.H. Nguyen, M.H. Tran, P.D.N. Nguyen, D.T. Tran and D.C. To: Anti-inflammatory xanthone derivatives from Garcinia delpyana. J. Asian Nat. Prod. Res., 20, 1-9 (2020).

Nurminah, M., T. Karo-karo, and E.A. Sembiring: The physicochemical characteristics of dry gelugur slices (Garcinia atroviridis). IOP Conf. Ser.: Earth Environ. Sci., 305, 1-5 (2019).

Onakpoya, I., S.K. Hung, R. Perry, B. Wider and E. Ernst: The use of Garcinia extract (hydroxycitric acid) as a weight loss supplement:A systematic review and meta-analysis of randomised clinical trials. J. Obes., 2011, 509038 (2011). doi: 10.1155/2011/509038.

Oyaizu, M.: Studies on products of browning reactions: antioxidative activities of product of browning reaction prepared from glucosamine. Jpn. J. Nutr., 44, 307-315 (1986).

Qu, W., Z. Pan and H. Ma: Extraction modeling and activities of antioxidants from pomegranate marc. J. Food Eng., 99, 16-23 (2010)

Schieber, A., F.C. Stintzing and R. Carle: By-products of plant food processing as a source of functional compounds recent developments. Trends Food Sci. Technol., 12, 401-413 (2001).

Schobert, R. and B. Biersack: Chemical and biological aspects of garcinol and isogarcinol:recent developments. Chem. Biodive., 16, e1900366 (2019). DOI: 10.1002/cbdv.201900366

Singleton, V. L. and J. A. Rossi: Colorimetry of total phenolics with phosphomolybdic-phosphotungstic acid reagents. Am. J. Enol. Vitic., 16, 144-158(1965)

Tomar, M., R.P. Rao, P. Dorairaj, A. Koshta, S. Suresh, M. Rafiq, R. Kumawat, R. Paramesh, U.V. Babu and K.V. Venkatesh: A clinical and computational study on anti-obesity effects of hydroxycitric acid. RSCAdv., 9, 18578-18588 (2019).

Vani, T., M. Rajani, S. Sarkar and C.J. Shishoo: Antioxidant properties of the ayurvedic formulation, triphala and its constituents. Int. J. Pharmacogn., 35, 313-317 (1997).

Vega-Galvez, A., K.D. Scala, K. Rodriguez, R. Lemus-Mondaca, M. Miranda, J. Lopez and M. Perez-Won: Effect of air drying temperature on physicochemical properties, antioxidant capacity, color and total phenolic content of red pepper (Capsicum annuum, L. var. Hungarian). J. Food Chem., 117, 647-653 (2009).

Wong, S.Y.: The colorimetric determination of iron. J. Biol. Chem., 77, $409(1928)$ 